\title{
座の姿勢
}

野号影勇 (早稲田大学)

\section{A parametric model for seating}

K.Noro (Waseda Univ.)

座の姿勢は、どのように記述できるかに ついて、述べるまず、よく知られている メンタルモデルを比較としてあげる。

このモテルは、コンピューターとその操 作者が、相対して仕事をする、いわゆる VDT作業で、しかも、ティスプレイの表示 内容か、文字列の場合が、適当している。 人の何を記述しているかというと、名前が 示すとおり、人の頭脳についてである。応 用としては、コンピューターの操作手順や ソフトウエアの使いやすさのデザインであ る。

これに対して、ティスプレイや人の目の 位置や姿勢といった物理的な関係を記述す るモテルがある。このモデルは、極く少数 のパラメータで記述できることを、筆者 は、1983年に、視軸モデルとして発表した。 視軸モテルの考えは、次のようなものであ る。

まず、ディスプレイとそれを視る人は、 一本の見えない系で結ばれていると考え る。この見えない系を、視軸とよぶ。すな わち、視軸の一端に、ティスプレイ画面の
中心として、Aを結ぶ。もう一つの端には、 両眼を結ぶ直線の中心点 $\mathrm{B}$ を結ぶ。ここ で、図1 に示すパラメーターが、定義でき る。詳細は、引用・参考文献にゆずる。

注

視軸は、抽象概念であるが、ちょうど、電 車の車両同士をつなげる連結器やモーター のカップリングそして電気回路のインピー ダンス・マッチングなどとよく似た考え方 かもしれない。注終わり

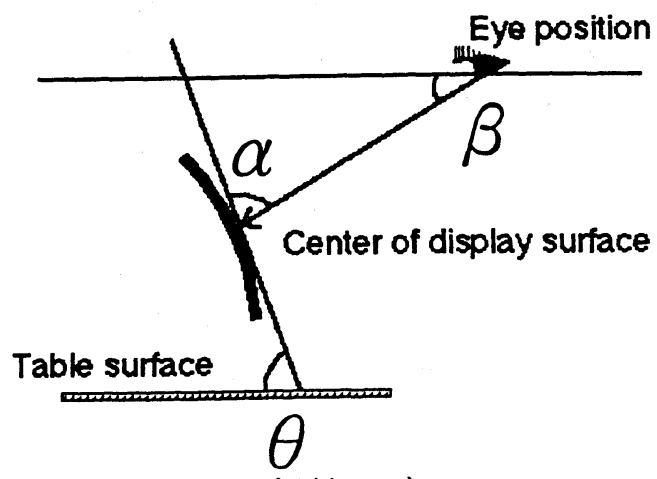

図 1 視軸モデル 
図 1 は、ティスプレイとオペレーターの関 係を記述するための視軸モテルである。

視軸の一端は、ティスプレイ画面の中心 $A$ 、他端は、両眼の中心点 $\mathrm{B}$ である。視軸 は、 $\mathrm{A}$ 点の立体角 $\alpha$ と $\mathrm{B}$ 点の立体角 $\beta$ で定 義される。したがって、ディスプレイとオ ペレータの関係は、立体角 $\alpha$ と $\beta$ およひ視 距離 L で規定される。このモテルは、座 の姿勢のモデルに容易に拡張できる。(図2)
すなわち、差尺を導入して、次式を関係式 とする。

座面・眼位間の垂直距離

$=$ 画面中心高 + 差尺 $+\mathrm{L} \cdot \sin \beta$

上記の関係は、オフィスでのVDT作業の ような、固定的なものを前提としている。 しかし、パラメータの定義域を拡張するこ とにより、多様な作業形態にも、対応可能

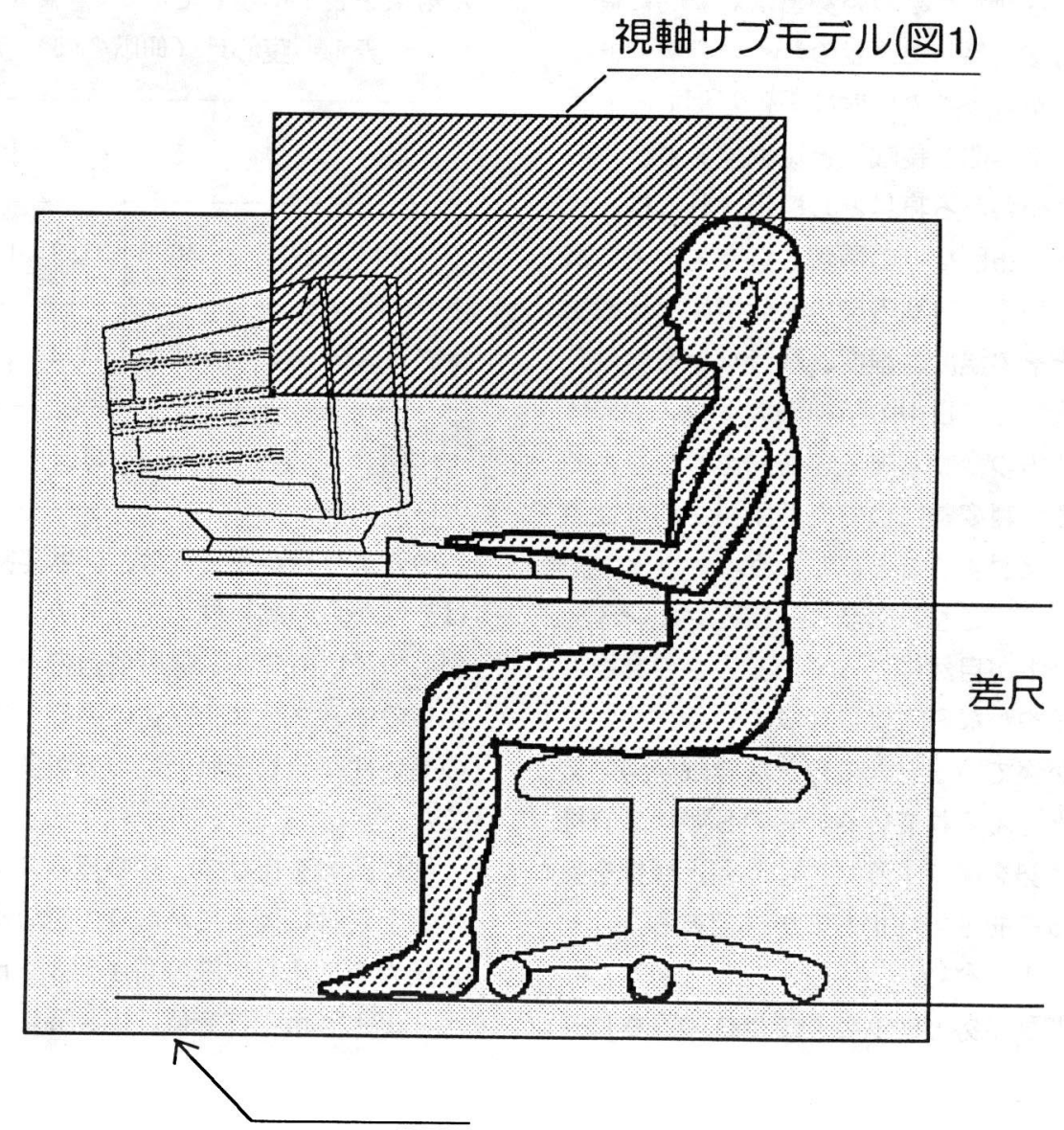

座面高、机高、ディスプレイ高を決

定するサブモテル (文中の式による)

図 2 二つのパラメトリックサブモデルの関係

引用文献 Noro,K. Sashaku : a user-oriented approach for seatng. 1994 (from Lueder and Noro (Eds.) Hard Facts about soft Machines, Taylor \& Francis) 